\title{
ANALYSIS OF THE COLOMBIAN MEDICAL TOURISM INDUSTRY FROM A SYSTEMIC COMPETITIVENESS APPROACHi
}

\author{
ANÁLISIS DE LA INDUSTRIA DEL TURISMO MÉDICO COLOMBIANO DESDE UN ENFOQUE DE \\ COMPETITIVIDAD SISTÉMICA
}

\author{
ANÁLISE DA INDÚSTRIA DO TURISMO MÉDICO COLOMBIANO DE UMA ABORDAGEM DE \\ COMPETITIVIDADE SISTÊMICA
}

\section{CITATION}

De la Puente-Pacheco, Mario A. (2018) Analysis of the Colombian medical tourism industry from a systemic competitiveness approach. Dimensión Empresarial 16(2), 111-122. DOI: http:/ /dx.doi.org/10.15665/dem.v16i2.1503

JEL: I10, I18

\begin{abstract}
This research article analyzes the role of the central government of Colombia in the strategy for the improvement of the medical tourism industry through a critical approach of the traditional model of competitiveness. Based on a mixed method, the feasibility of the associative systemic competitiveness model and its effectiveness on the quality of medical services offered to foreign patients is determined. The proposal for the implementation of systemic competitiveness model improves the perception of quality of medical services by foreign patients. To implement the proposed model, it is recommended the expansion of free taxation zones, the proliferation of medical service clusters and the strengthening of strategic alliances with international operators.
\end{abstract}

Keywords: Systemic competitiveness, Medical tourism, Government role, Traditional competitiveness model, Heath tourism

\section{RESUMEN}

Este artículo de investigación analiza el papel del gobierno central de Colombia en la estrategia de posicionamiento del turismo médico a través de un enfoque crítico del modelo tradicional de competitividad. Con base en un método mixto, se determina la viabilidad del modelo asociativo de competitividad sistémica y su efectividad en la calidad de los servicios ofrecidos a pacientes extranjeros. La propuesta para la implementación del modelo de competitividad sistémica mejora la percepción de la calidad de los servicios médicos por parte de pacientes extranjeros. Para implementar el modelo propuesto, se recomienda la expansión de las zonas libres de impuestos, la proliferación de clústeres de servicios médicos y el fortalecimiento de alianzas estratégicas con operadores internacionales.

Palabras clave: competitividad sistémica, turismo médico, papel del gobierno, modelo de competitividad tradicional, turismo de Heath

\section{RESUMO}

Este artigo de pesquisa analisa o papel do governo central da Colômbia na estratégia para a melhoria da indústria do turismo médico através de uma abordagem crítica do modelo tradicional de competitividade. Com base em um método misto, determina-se a viabilidade do modelo associativo de competitividade sistêmica e sua efetividade na qualidade dos serviços médicos oferecidos a pacientes estrangeiros. A proposta de implementação do modelo de competitividade sistêmica melhora a percepção da qualidade dos serviços médicos por pacientes estrangeiros. Para implementar o modelo proposto, recomenda-se a expansão de zonas de tributação livre, a proliferação de clusters de serviços médicos e o fortalecimento de alianças estratégicas com operadores internacionais.

Palavras-chave: Competitividade sistêmica, Turismo médico, Papel do governo, Modelo de competitividade tradicional, Turismo de saúde. 


\section{INTRODUCTION}

The international medical tourism is the voluntary mobility of patients to foreign countries searching affordable and high-quality treatments. The growing need to meet the demand for medical procedures outside the country of origin due to local market failures have increase the international mobility, through agreements between insurance companies and the travel of patients who seek healthcare procedures in many cases without knowing the legal and physical risks. The travel of patients also obeys to competitive advantages that each country develops and that patients can identify. The travel to developing countries is due to the low prices and lower legal restriction of medical procedures against developed countries.

In the case of Colombia, the patients come mainly from the United States, Canada, Aruba, Antilles and Panama looking for procedures in cardiology, urology, orthopedics and cosmetic surgery at lower prices than in their countries of origin. The private sector has been the main protagonist of the industry growth limiting the role of the central government to a regulator of medical services that are offered to national and foreign patients. The dynamics of the local industry has followed the model of Porter (1990) in which competitiveness is an end and the government have a limited role in the industry's international competitiveness. However, under the current model the medical industry has not had enough incentives or spaces to position its offer of medical procedures abroad.

This article analyzes the role of the central government of Colombia in the promotion and positioning of medical tourism based on the Porter model and proposes the application of the systemic competitiveness model of associative character based on Rugman and D'Cruz (1993) approach as an alternative view for the integral improvement of the industry. This study based on a mixed method begins with the dynamic's description of Colombian medical tourism industry.
Next, the main theories of competitiveness are detailed from the traditional view of Porter to the alternative approaches of competitiveness with an associative character. Then the role of the central government in the promotion and strengthening of the national industry through the efficiency of executive orders under the traditional competitiveness model is studied.

Also the potential effects of the implementation of the systemic competitiveness approach in Colombian medical tourism is analyze through an experiment that compares the perception of quality of medical services to 200 foreign patients, of whom 100 were attended in clinics with public support of the local governments following the systemic competitiveness approach, and the other 100 were attended in clinics that do not have such support. The purpose of this experiment is to identify if a governmental support for the promotion and positioning of medical services in Colombia improves the perception of quality by foreign patients. The general objective of this research is to analyze the role of the national authority in the promotion and improvement of medical services through the vision of systemic competitiveness as a more efficient form of sectorial development.

The instruments for conducting this study were a survey of quality perception to 200 foreign patients who consumed medical procedures in accredited and nonaccredited clinics, executive orders of the central government of Colombia that establishes the route map of the industry and consulting reports describing international medical tourism market and the Colombian case.

\section{DYNAMICS OF COLOMBIAN MEDICAL TOURISM}

The medical tourism industry is a still incipient sector; at the beginning of the year 2016 achieved around 100,833 patients. According to the Ministry of Industry and Commerce (2016), patients who traveled to Colombia 
looking for healing procedures were approximately 10,117, while the ones who traveled for aesthetic procedures and preventive medicine were 2,351. However, the wellness procedures are the ones that attracted the most patients with a total of 88,405 in 2016 (Procolombia, 2016).

The demand for medical services is based on the search for procedures at lower costs compared to developed countries such as the United States which is the first patient's exporter to Colombia. According to the Productive Transformation Program (2017) during 2013-2016 there was a decrease in the demand for medical services in $42.3 \%$ due to variable causes such as exchange rate volatility and the limited preparation of clinics that receive patients in the follow-up of internationally accepted protocols. According to the McKinsey \& Company (2016), non-invasive medical procedures are expected to increase the foreign demand due to multiple factors. The first is that more tourists are looking for alternative experiences and enriching their knowledge about the destination where they go. The second is that direct investments in this category are lower compared to those of curative and preventive medicine, where infrastructure is needed for highly complex procedures with medical and technological equipment. Medellin, Bogota and Cali are the cities with the largest foreign patient's reception with $75.3 \%$ of total consumption helped by the adaptation of public spaces and tax incentives by local governments for highly complex clinics.

The international positioning strategy of the industry includes patient loyalty (mainly foreigners and Colombians abroad, although national patients with high purchasing power are not discarded), and preference of national medical procedures that include the combination of interventions, aesthetic and wellness treatments with the possibility of knowing the tourist attractions of Colombia. The improvement of the industry goes hand in hand with international accreditations of clinics of the highest quality as a vehicle to attract foreign patients and increase strategic alliances with international medical service providers such as insurance companies, guilds of the international healthcare sector, research and development that could increase Colombian physician's recognition abroad. In that sense, there are four clinics with accreditation from the Joint Commission International (2017) and the Global Healthcare Accreditation Program (2017) in medical procedures of high complexity that serves as a reference for foreign patients and insurance companies to send their clients to consume medical procedures.

\section{SYSTEMIC COMPETITIVENESS OF ASSOCIATIVE CHARACTER: A THEORETICAL APPROACH}

It is difficult to study competitiveness as a paradigm when it is still confusion and ambiguity about the concept, leaving a void in theoretical and practical clarity (Hillebrand, Messner, \& Meyer-Stamer, 2013). The book The Competitive Advantage of Nations (Porter, 1990) is a first conceptual approach to the competitiveness idea as an end based as the capacity of national enterprises to sustain and increase their participation in international markets with a parallel rise in the standard of living of the population. Figure 4 shows the diamond of competitiveness of Porter.

The definition is complemented by the diamond model (figure 1) that is characterized by the allocation of four elements that skyrocket the participation of industries in international markets: 1) the conditions of factors, 2) the context for the strategy and business rivalry, 3) the conditions of demand, 4) the related industries and support. The main criticism of Porter's model is the government role as exogenous agents that should have a limited influence in the local companies' fight for international markets share. Although the inclusion of the government element implies better exogenous conditions for companies to increase the market share, there is no analysis of how the four factors influence the 
government in its role as a regulator and promoter of the companies' competitiveness.

Figure 1: Diamond of competitiveness

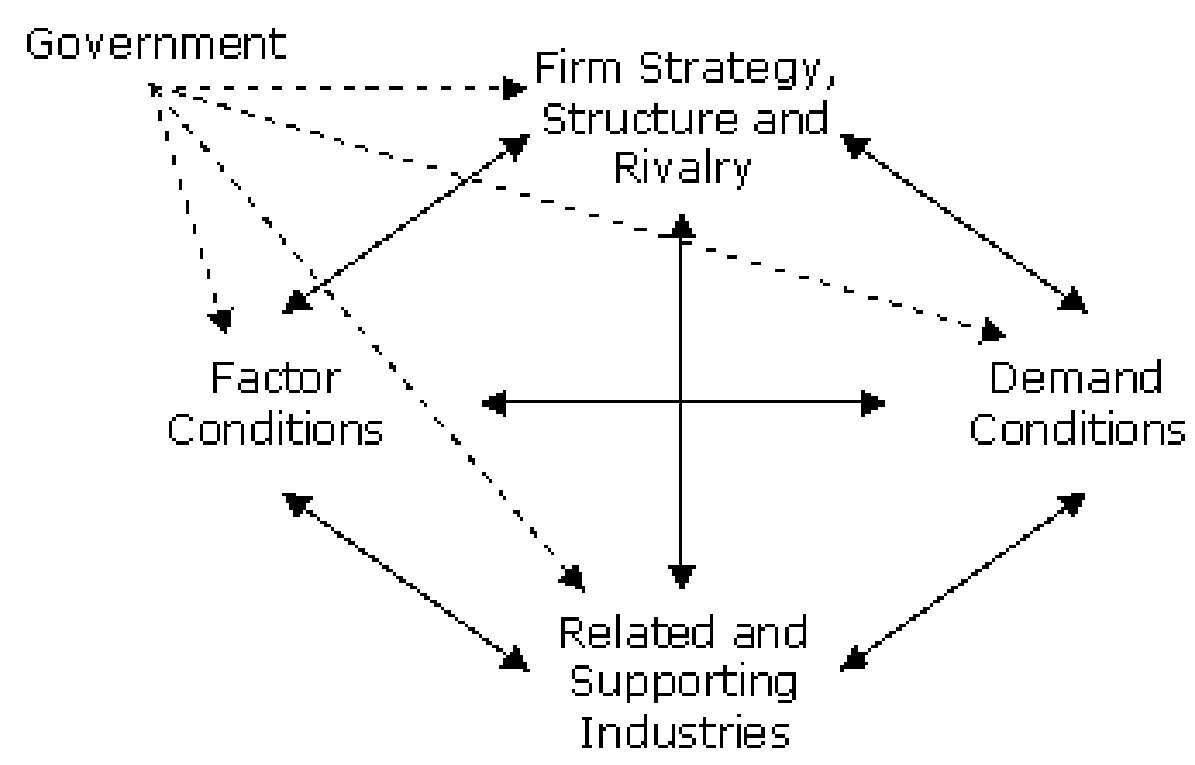

Source: Porter, M. (1990).

Rugman and D'cruz (1993) include the government element in the Porter's initial diamond as illustrated in Figure 2, manifesting a more participatory approach in the generation of spaces that creates greater market share to national companies based on complementary elements, as the result of increasingly competitive environments in which the technological differentiation of both processes and the use of digital media strengthens the output production, marketing, sales and loyalty service of wholesale and retail consumers. In this sense, competitiveness is assumed as a mere business case excluding social consequences (both positive and negative) of multiple dimensions (educational, labor inclusion) in addition to the absence of spaces for nontraditional industries that enables the export diversification and sales in general.

Jones (2002) relate the concept of competitiveness to the commercial performance of companies of different legal natures, with the increase of their assets and improvements in population's welfare (quality of life, employment, impact on the environment), vertical integration, innovation, efficient management of resources, incorporation of new technology, decentralization of production, etc.; relating the three levels of competitiveness: business competitiveness, national competitiveness and industrial competitiveness. De la Puente (2015) establishes that business competitiveness results from the allocation of goods and services while national competitiveness relates to the generation of an environment conducive to industrial competitiveness. That is, the government as a regulating agent and facilitator of economies of scale moving away from the perspective of Porter and Rugman in the sense of indirect promoter of international trade.

Unlike the traditional perspective mentioned above on the generic concept of competitiveness in which the government is only a regulator, facilitator and promoter of the expansion of market niches for national 
companies focused on favorable macroeconomic conditions (which visualizes competitiveness as a result of the conditions of "macro" variables and their influence on the costs of production and factor prices), the neolaborism (which mentions that labor is essential for a competitive advantage, assigning investment an equal importance) and institutionalism (which gives importance to the role played by institutional aspects in management, innovation and learning) are include in the systemic competitiveness approach. Systemic competitiveness is the result of a complex and dynamic interaction patterns between the government of a country, companies, intermediary institutions and the organizational capacity of a society; this model is based in four levels: micro, meso, macro and meta.

Figure 2: Diamond competitiveness of Rugman and D'cruz (1993).

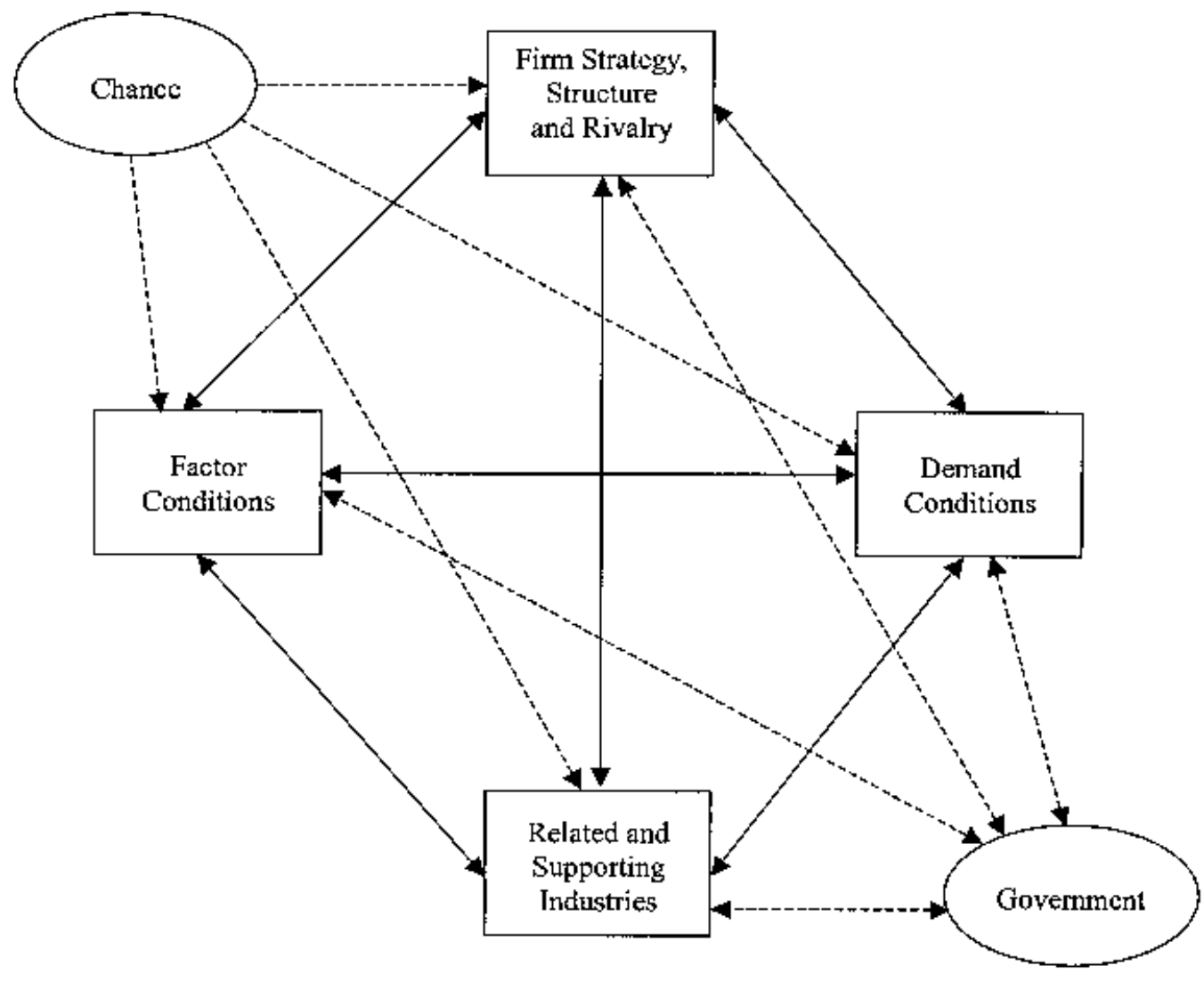

Source: Rugman, A. M., Cruz, J. R.: (1993)

Systemic competitiveness is characterized by recognizing that the success of an industrial development is not only achieved by a production function at the micro level, or because there are stable macroeconomic conditions, but also because there are government measures and policies that encourage competitiveness in companies or organizations from the combination of an environment that incentives social, judicial, political and macroeconomic stability, including the adaptation of socio-cultural elements that projects social competitiveness (target level). According to the Organization for Economic Co-operation and Development (OECD) report Developing of OECD Competitiveness Indicators Platform it is summarized and systematized these approaches into a comprehensive vision that it is called "structural competitiveness" (OECD, 2016). At the micro level, the expansion of the government presence in production and sale of goods 
and services is highlighted, based on its strategies for brand positioning, economies of scale and consumer loyalty (if applicable). The meso level relates to the limited co-operation networks of business organizations that require the participation of government and nongovernmental agents; in this way, the policies that create the meso level have a cross-national policy dimension. Figure 3 illustrate systemic competitiveness model of Altenburg, Hilebrand \& Meyer-Stamer (1998).

This is the case of improved access and quality of public services, increased coverage and methodological quality of the education system from various angles, universal coverage of access to a high quality of the health system, strategies for positioning goods and services abroad, promotion of domestic and foreign investment, both direct and indirect, to enhance competitive advantages. For the macro level to have an effect on the overall strategy of systemic competitiveness, it must be ensured some stable macroeconomic conditions, as well as achieving the objectives of economic growth and competitiveness. To achieve the goal level, it is necessary to coordinate the objectives of the previous levels, taking into account the scope of a long-term welfare state (understood as the change in the concept of information sharing between competitors, state agents, civil society, consumer responsibility to determine the positive and negative impacts in business organizations, the ability to formulate sectorial strategies, policies that imply an improvement of civil society, and social cohesion through incentives, not imposition through coercion). On the other hand, it is at this level that the social structure that complements the economic structure takes shape, so that networking, horizontal coordination and social integration must be strengthened (Espinosa \& Jackson, 2002).

\section{ACTIONS OF THE CENTRAL GOVERNMENT IN MEDICAL TOURISM UNDER THE CURRENT MODEL OF COMPETITIVENESS}

The documents of the National Council for Economic and Social Policy (NCESP) which belong to the National Planning Department of Colombia seeks to establish roadmaps that promote the improvement of the medical tourism industry following the traditional concept of competitiveness in which the central government is an outsider that does not get involve indirectly in the improvement of the industry. One of the documents of the NCESP which promotes greater dynamism in the Colombian medical tourism is the number 3678 of 2010 called National Policy Productive Transformation and Promotion of Micro, Small and Medium Enterprises: A Public and Private Effort that seeks a higher level of productivity of micro, small and medium-sized enterprises through the facilitation of both financial instruments such as capital, as well as access to markets that allows greater participation of its productive activity and in the generation of human resources of high quality. Another document number is the 3582 of 2009 called National Policy of Science Technology and Innovation which secures financial resources for the training of physicians and nurses in 1.2 million dollars for exchange programs for the learning of a second language and availability of resources for medical research in the United States or European research centers.

The specific objectives of document 3582 are as follows: 1) To foster innovation in productive systems; 2) To consolidate the institutional framework of the National System of Science, Technology and Innovation; 3) To strengthen human resource for research and Innovation, 4) to promote the social appropriation of knowledge and 5) Focus public action in strategic areas. Another objective is to consolidate the intellectual property system by developing the guidelines formulated by the document 3533 of 2008 called Bases of a plan of action for the adaptation of the intellectual property system to competitiveness and national productivity 2010-2020, so entrepreneurs find 
reward for their innovation efforts and take advantage of intellectual property to empower technology transfer processes.

However, De la Puente (2017) mentions that although there are three independent strategies to improve Colombian medical tourism through the administrative documents presented, each one is being implemented in an isolated way without each being complemented with the other two to generate a comprehensive strategy. This is because according to the current competitiveness model, clinics, health personnel, national insurers and intermediaries are the only agents that must act actively to specialize the provision of medical services to attract foreign patients.

Figure 3: Systemic competitiveness

\section{Determinants of Systemic Competitiveness}

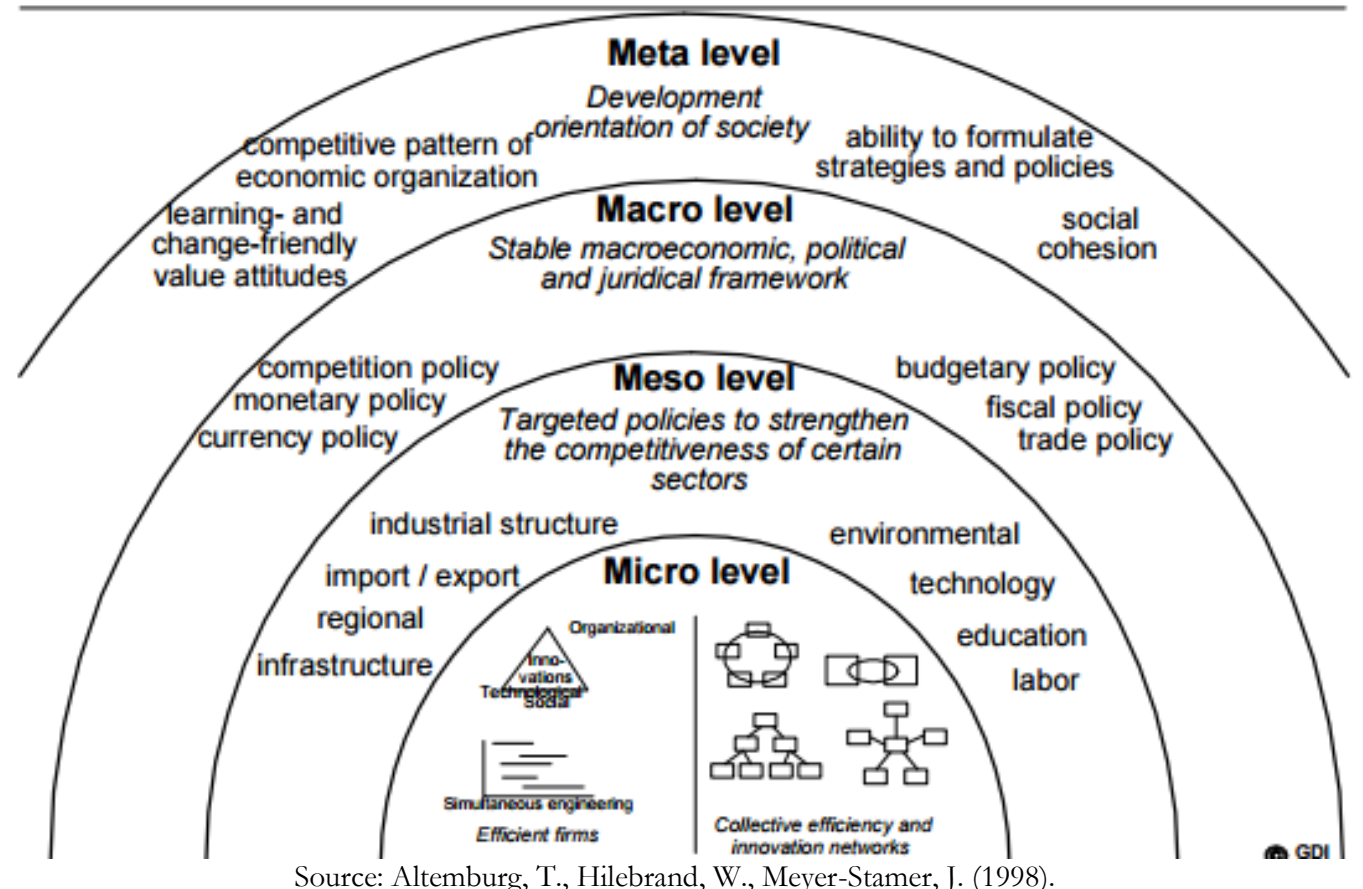

According to Arias and Matos (2012) the current model of industrial development limits the co-operation between central government agencies for the promotion of Colombian medical tourism due to the bureaucratic limitation that prevents an efficient location of monetary and non-monetary resources. This affects the international presence of national clinics that have international accreditation in high quality medical care in several procedures, despite the efforts of Colombia's trade and investment promotion agency (Procolombia, 2016). Also, under the current competitiveness, the strategies for positioning the industry abroad are implemented in an isolated way in which the public promotion and regulating agencies does not share the same view. According to Arias, Matos and Caraballo (2016) a proof of this is the inconsistency between the strategies focused on the administrative documents presented above and the Colombian commercial policy according to the ministry of commerce in which it is expected that oil exports increase its participation in the trade balance while other entities such as Procolombia 
are looking for a more diversified international commerce.

On the other hand, the measures for positioning industry does not include factors for the improvement of social cohesion, which means that other agents who are indirectly affected by the implementation of these strategies are not considered. According to Conell (2011), medical tourism is perceived as a source of inequity in health services in which only those with monetary resources can consume high-cost medical procedures while health systems in developing countries spend more time adapting and training to attend foreign patients.

According to the Productive Transformation Program (2017) the perception of the population in general about medical tourism is that it is an industry far from the interests of the citizens which make it less considered for the planning and implementation of industrial policies by the central government.

The immediate effect is the domain of private agents in the structuring of international medical offer prioritizing the application of measures that attract patients with greater monetary capacity. According to De la Hoz \& Leiva (2016) the negative externalities of Colombian medical tourism coupled with a strategy application that does not include agents who are indirectly affected, creates a distortion of the perceived benefit of the industry with negative consequences for its national positioning. However, local governments who implemented the model of systemic competitiveness have generated spaces of promotion of the sector in local and foreign scenarios, so it is not perceived as far from the general population's interests. This is the case of Medellin that through joint commissions that integrate the local government representatives and medical operators, have established a roadmap for the industry to grow in accordance with the global vision of the local authorities.

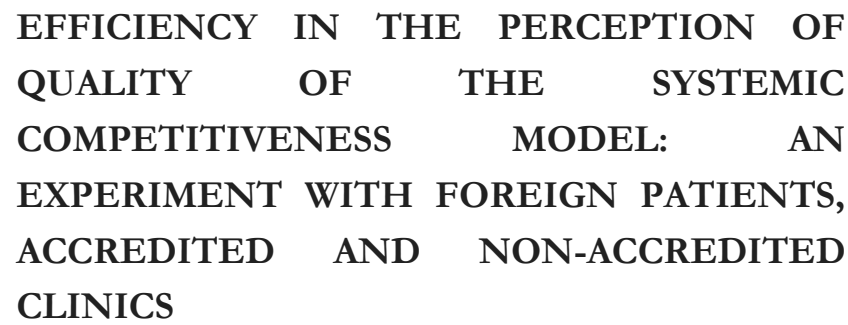

According to the Medical Tourism Association (2014) the quality of medical procedures is determined by multiple independent variables reflected in international accreditations of clinics that offer healthcare services to national and foreign patients. According to Mason and Wright (2011), having some international accreditations increases the possibilities of strategic alliances with international medical centers, as well as improves the perception of the confidence of foreign insurers for the transfer of patients. In Colombia, five medical centers have JCI and GHAP accreditations that serve $64.2 \%$ of total foreign patients who consume medical services in Colombia (De la Puente, 2017). These clinics are: 1) Imbanaco Medical Center, 2) The Cardiology Institute, 3) Cardiovascular Clinic of Colombia, 4) Hospital Pablo Tobon Uribe, 5) University Hospital Santa Fe de Bogota.

To determine if the international accreditations obtained by the five clinics improve the quality of the medical procedures offered, 200 foreign patients who consumed medical procedures were surveyed, of which 100 did so in the five accredited clinics and the other 100 in 5 other clinics without international accreditation. The survey rates several items in the scale of 1 to 5 of which 1 reflects a low perception of quality and 5 a high perception of quality.

The rate of quality of the accreditation-group and nonaccreditation group are compare through arithmetic means to determine whether an international accreditation improve the performance in medical care. To compare the quality perceptions, it is necessary to know the arithmetic means through a T-test for independent samples. It is considered two initial tests: 
the normality test and a variances test. Table 1 expose the statistical inputs that will be use:

Table 1: Statistical inputs

\begin{tabular}{|l|c|c|}
\hline & Non-Accredited group & Accredited group \\
\hline Recount & 23 & 22 \\
\hline Average & 3,83 & 4,03 \\
\hline Standard deviation & 0,3 & 0,44 \\
\hline Variance of coefficient & $7,85 \%$ & $10,92 \%$ \\
\hline Minimum & 3,1 & 3,4 \\
\hline Maximum & 4,2 & 4,9 \\
\hline
\end{tabular}

Source: author. Calculation based on SPSS.

Before comparing variances, it is necessary to check the normality condition of the grades. Since we have a small amount of data we use the Kolmogorov-Smirnov test. The results are illustrated in Table 2:

Table 2: Normality test result

\begin{tabular}{|l|l|l|}
\hline & Statistical value & P values \\
\hline Non-Accredited group & 0.154 & 0.650 \\
\hline Accredited group & 0.206 & 0.307 \\
\hline
\end{tabular}

Source: author. Calculation based on SPSS.

Since the P values for both tests are high, the decision in both cases is to consider that the scores are normally distributed with the values of the estimated parameters. To compare the variances an F-Fisher test was used. Value of the statistic $\mathrm{f}=0.47$. Value $\mathrm{P}=0.082$. At a significance level of 0.05 , the hypothesis of equality of variances is rejected, it is possible to consider that the variances are different. A T-test for the difference of means is used, from independent samples. Value of the statistic: $\mathrm{t}=-1.78$. P-value $=0.083$ at a significance level of 0.05 . Since the calculated P-value is greater than 0.05 , the hypothesis can be rejected. That there are differences between means. However, as P-value and significance level are very close the difference is not significant. The above means that clinics with international accreditation supported by local governments through the systemic competitiveness model offer better quality in medical procedures offered than those clinics that do not have international accreditation. That is, foreign patients perceive clinics with international accreditation as a better quality in medical care than those that do not have this instrument.

According to this statistical test, the application of the systemic competitiveness model, exogenous elements such as the adequacy of public space, generation of safe environments for patients implies a greater efficiency and perception of quality of national medical procedures. 


\section{RECOMMENDATIONS FOR THE APPLICATION OF THE SYSTEMIC COMPETITIVENESS MODEL AT NATIONAL LEVEL}

The implementation of the systemic competitiveness model goes through a greater synergy between the objectives of the central government and the clinics of high complexity through spaces of dialogue. Given that, the proposed model is based on involving non-state agents and that the government adopts a more active role towards the international positioning of the industry.

According to the Productive Transformation Program (2016), a successful case of creating a health cluster was the private "Travel Medic" initiative that, through the collaboration of related companies (hotels, clinics, financial support from public and private banks for investment in non-traditional sectors and medical schools) was coordinated for the creation of technical training programs. (McKinsey \& Company, 2009).

The Travel Medic Association was born from the initiative of six companies from the city of Manizales belonging to the health, hotel and tourism sector, which were united in the following objectives:

- To provide healthcare services based on physicians and nurses who speak English, high technology and competitive prices; in addition to first-class hotel care;

- To internationalize the services for each of the founding companies as a strategy of expansion and growth in other markets.

The Productive Transformation Program (2016) also recommends the expansion of free-tax zones as spaces with lower direct taxes in exchange for the settlement of clusters and clinics that are suitable for the attention of national and foreign patients accredited internationally by both JCI and GHAP.

One notorious case is the permanent free-tax zone located in the city of Barranquilla which offer health services such as pediatric, vascular and aesthetic care for adults and newborns, cardiopulmonary rehabilitation, preventive medicine program, pre-anesthetic and diagnostic services, among others. Inaugurated in 2013, has 112 beds, 164 offices and specialized diagnostic centers. This has accelerated the consumption of healthcare services of foreign patients and increased the quality of medical procedures through international accreditations different from JCI and GHAP.

On the other hand, the health care cluster located in the free-tax zone in Barranquilla has an international support office for patients who want to know more about the medical procedures offered which provides information on the requirements that the government of Colombia demand to grant a visa to consume medical procedures in the country, and facilitate the communication between the physician in the country of origin who know the health situation of the patient with the physician in Barranquilla in charge of the medical procedure.

\section{CONCLUSIONS}

Medical tourism in Colombia is a still incipient industry with prospects of growth in cities with greater adaptation of their clinics for the medical care of foreign patients. Under the current model of competitiveness there are three administrative strategies that are implemented in an isolated way that although they focus on improving variables such as that the physicians and nurses speak English fluently or strengthen the strategic alliances between the national and foreign clinics so the industry has more international recognition, the role of the central government is limited and not focused on the industry needs. Through a statistical analysis applied to patients who consumed medical procedures in accredited and non-accredited clinics, it was found that those in which local governments act more actively to improve the quality of medical services and support the obtaining of international accreditations of health centers, have a higher quality of services offered than those that do not. 
The implementation of the proposed model is based on more than just the generation of spaces for investment in the construction of clinical infrastructure, such as a more active role of the central government so the exogenous variables that creates a better quality of medical procedures such as security, adaptation of public spaces and tax deduction incentives rise the quality of medical services offered abroad. In that sense, tax-free zones, clusters and the combination of medical procedures with tourist activities increase the possibilities of international positioning of Colombian medical tourism.

\section{REFERENCES}

Altemburg, T., Hilebrand, W., Meyer-Stamer, J. (1998). Building Systemic Competitiveness Concept and Case Studies from Mexico, Brazil, Paraguay, Korea and Thailand. Available at http://www.meyer-stamer.de/1998/sysco98.pdf

Aria, F., Matos, A. (2012). Health tourism: Concept, history, development and current state of global market. Clio America, 6, 75-77.

Arias, F., Matos, R., Caraballo, M. (2015). Medical Tourism: Characterization the Offer in the District of Cartagena. $1^{\text {st }}$ Cartagena: Ed. Bonaventuriana.

Colombian Association of Cosmetic Surgery. (2017). About Us. Available at https://asociacioncolombianadecirugiacosmetica.com/

Colombian Society of Aesthetic and Reconstructive Plastic Surgery. (2017). Manual of Risk Preventions in Reconstructive Plastic Surgery. Available at https://www.cirugiaplastica.org.co/seguridad-del-paciente.html

Conell J. (2011). Medical Tourism. A new inequality? Privatisation, urban bias, migration and medical tourism. Asia Pacific Viewpoint, 52, 260-271.

De la Hoz, A., \& Leiva, F. (2016). Analysis of the determinants on the predisposition to visit a wellness tourism destination. Typologies of potential tourists. Tourism \& Management Studies, 12, 84-95.

De la Puente, M. (2016). Health Tourism: International Dynamics and the Colombian Case. Barranquilla: Uninorte Editions.

De la Puente, M. (2015). Dynamics of International Health Tourism. Revista Dimension Empresarial, 13, 2, 167-184.

Espinosa, A. \& Jackson, M. (2002). A systemic look at educational development programs: Two perspectives on a recent Colombian experience. Kybernetes. 31, 1324-1335.

Global Healthcare Accreditation Program. (2017). Global Healthcare Accreditation Standards Brief 4.0. Available at http://globalhealthcareaccreditation.com/wp-content/uploads/2017/05/GHA_STANDARDS_BRIEF_4.0.pdf

Hillebrand, W., Messner, D., \& Meyer-Stamer, J. (2013). Systemic Competitiveness: New Governance Patterns for Industrial Development. New York: Frank Cass.

Hotels and Tourism Association of Colombia (2014). General Statistics. Available at http://www.cotelco.org/estudiose-investigacion/ [15/08/2017]

Joint Commission International. (2017). Accredited Organizations. Available at http:/ /www.jointcommissioninternational.org/about-jci/jci-accredited-organizations/?c=Colombia [10/09/2017]

Jones, A. (2002). Cluster and market failure in the small business sector. In: Competitiveness Institute 5th Annual Global Conference, 10-12 October 2002; Canberra: CIGC; 2002. p. 14-21.

Mason, A., \& Wright, K. (2011). Framing medical tourism: An examination of appeal, risk, convalescence, accreditation, and interactivity in medical tourism web sites. Journal of Health Communication, 16, 163-177.

McKinsey \& Company. (2016). Colombia's Lesson in Economic Development. Available at http:/ /www.mckinsey.com/global-themes/americas/colombias-lesson-in-economic-development [12/07/2017].

McKinsey \& Company. (2009). Developing Sector of World Class. Available at http:/ / www.ptp.com.co/documentos/Plan\%20de\%20Negocios\%20Turismo\%20de\%20Salud.pdf [12/11/2017].

Medellin Chamber of Commerce. (2016). Health Tourism in the International Context and Conditions for Access to the Market. Available at http://www.politecnicojic.edu.co/images/downloads/publicaciones/revistainterseccion/interseccion-03/pdf/turismo-salud.pdf [30/07/2017].

Medical Tourism Association. (2014). Wellness Tourism: A Trillion Dollar Future? Available at http://www.medicaltourismassociation.com/upload/upload_WELLNESS_WHITEP APER-1.pdf [[12/10/2017].

Ministry of Industry and Commerce. (2016). Health Tourism and Collaborative Experience 2016. Available at http://www.mintic.gov.co/portal/604/w3-article-27239.html [1/12/2017].. 
National Planning Department. (2010). Document 3678 of 2010. Production Transformation Policy: A Model of Sectorial Development for Colombia. Available at https://colaboracion.dnp.gov.co/CDT/CONPES/Econ\%C3\%B3micos/3678.pdf [10/10/2017].

National Planning Department. (2009). Document 3582 of 2009. National Policy of Science Technology and Innovation Available at http:/ / www.colombiacompetitiva.gov.co/sncei/Documents/conpes-3582-de-2009.pdf [12/11/2017].

National Planning Department. (2008). Document 3533 of 2008. Bases of a plan of action for the adaptation of the intellectual property system to competitiveness and national productivity 2010-2020. Available at http://www.ica.gov.co/getattachment/a1be26c2-af09-4635-b885-c3fcea7291e4/2008cp3533.aspx [22/10/2017]

Organisation of Economic Co-operation and Development. (2016). Developing of OECD Competitiveness Indicators Platform. Available at https://www.oecd.org/mena/competitiveness/44965863.pdf [25/11/2017].

Oxford Business Group. (2017). Colombia 2016. Available at https://www.oxfordbusinessgroup.com/node/902258/reader [12/04/2017]..

Porter, M. (1990). Competitive Advantage of Nations. New York: Free Press.

Procolombia. (2016). Health and Medical Tourism. Available at http://tlceeuu.procolombia.co/sites/default/files/2._turismo_de_salud_en_colombia_0.pdf [28/05/2017].

Productive Transformation Program. (2016). Dynamics of Colombian Medical Tourism. Available at: https://www.ptp.com.co/documentos/Plan\%20de\%20Negocios\%20Turismo\%20de\%20Salud.pdf [14/05/2017].

Rugman, A., Cruz, J. (1993). The double diamond model of international competitiveness: The Canadian experience. MIR: Management International Review, 33, 17-39.

Vijaya, R. (2014). Medical tourism: Revenue generation or international transfer of healthcare problems? Journal of Economic Issues, 44, 53-70.

World Development Indicators. (2015). Compound Indicators. Available at http:/ / data.worldbank.org/sites/default/files/wdi2014-highlights.pdf [23/05/2017]

\section{NOTES}

\footnotetext{
' Research article. This research has been supported by the Department of Political Science and International Relations of Universidad del Norte, Barranquilla, Colombia, www.uninorte.edu.co. Reception date [22/11/2017], fecha de aceptación [10/04/2018].
}

\section{AUTHOR}

Mario Alberto de la Puente Pacheco

Professor-researcher of the Department of Political Science and International Relations of the Universidad del Norte, Barranquilla, www.uninorte.edu.co. PhD in International Economic Analysis, Universidad Rey Juan Carlos. Member of the research group International Agenda endorsed by the Department of Science and Technology of Colombia (COLCIENCIAS).Contact: mdelapuente@uninorte.edu.co. 